DOI https://doi.org/10.30525/978-9934-26-180-0-18

\title{
CLASSROOM ASSESSMENTS AS A POWERFUL MEANS OF MOTIVATION
}

\author{
Zelenska O. M. \\ Candidate of Pedagogical Sciences, Associate Professor, \\ Assistant Professor at the Department of Aviation English \\ of the Postgraduate Education Faculty \\ Ivan Kozhedub Kharkiv Air Force National University \\ Kondra O. V. \\ Senior Lecturer at the Foreign Language Department \\ of the Postgraduate Education Faculty \\ Ivan Kozhedub Kharkiv Air Force National University \\ Kharkiv, Ukraine
}

One of the top issues in ELT is the motivation of the students. To master any skills or develop any abilities in any area successfully, a person is to be motivated. When learning a foreign language, motivation is especially essential. The level of progress depends on that greatly. In other words, sufficient curricula and good explanations in class are not enough to get a success. The essence of an educational process is transferring knowledge from teacher to students. And the final result depends, first of all, on regular efforts of students who need to be motivated for that.

When a person learns a foreign language, both affective and cognitive qualities are activated. Cognitive qualities are the ability to learn languages and the intelligence in general; affective qualities are attitude and motivation. The last are variable and influenced; and affect the process of learning to a large extent.

We cannot directly motivate students. But we can create acceptable and safe atmosphere in the classroom, make teaching and learning stimulating and attractive, use methods that are interesting and relevant for students.

Adherence to the principles of AFL (assessment for learning) in teaching English greatly meets these requirements. One of the key principles of AFL is that the evaluation of progress takes place not only at the end of a module, a semester, a course or an academic year, but at every stage of learning when it is necessary, depending on progress.

The principles of AFL were developed by Paul Black and Dylan William, UK professors, at the beginning of this century. They made a substantial 
research on how to have a success in the process of teaching and learning and drew up the main principles.

Assessment for learning is referred to as formative assessment, i.e. the process of collecting and interpreting evidence for use by teachers and learners to decide where they are in their learning, where they need to go, and how best to get there (Assessment Reform Group, 2002) [2, p. 4-5].

Formative assessment refers to a wide variety of methods that teachers use to conduct in-process evaluations of student comprehension, learning needs, and academic progress during a lesson, unit, or course. Formative assessments help teachers identify concepts that students are struggling to understand, skills they are having difficulty acquiring, or learning standards they have not yet achieved so that adjustments can be made to lessons, instructional techniques. The general goal of formative assessment is to collect detailed information that can be used to improve instruction and student learning while it's happening. What makes an assessment «formative» is not the design of a test, technique, or selfevaluation, per se, but the way it is used-i.e., to inform in-process teaching and learning modifications.(The Glossary of Educational Reforms, 2014) [6].

Apart from formative assessment, the key principle of ALF is referred to as special climate in the class that encourages students to take an active part in the learning process actively and helps them to gain confidence that their progress depends on their efforts. To contribute to such atmosphere in class, the teacher uses specific feedback and self-assessment, gives students exact, more detailed information and precise objective of studying, pays attention to their individuality for better understanding, and adjusts the teaching to their needs. Confidence and self-assessment of students increase due to such cooperation.

To have a permanent feedback between a teacher and a student, we need to manage the process of learning and monitor the progress made by the students at different stages. The best tool for that is often testing. The lower students' level is, the more often they may need testing.

A test, in simple terms, is a method of measuring a person - ability, knowledge, or performance in a given domain [4]. That is, testing makes it possible to assess the abilities and competence of a person in a particular field and monitor his progress at the given moment.

The test may be a means of eliciting linguistic data which is the object of their study, or it may be intended to provide information on linguistic proficiency for purpose of comparison with some other linguistic variable [1].

When we test target language often, we are able to obtain true information on whether the methods of teaching were adequate and effective, get clues as for how to improve teaching and learning strategies. We can get valuable results about the importance of progress made by students, decide what target language 
is to be covered and reviewed, how teaching and languages strategies need to be adjusted. Due to these moments testing is worth including into every language course regardless of whether the teacher adheres to the AFL principles or not.

Using the AFL principles highlights what target language will be reviewed by students and helps them to evaluate their progress. Testing that takes place often, at any phase of studying, is called teaching testing. Teaching testing can motivate and encourage students. The feedback after the test can show what they do not understand.

The effect of testing on teaching and learning is known as backwash, and can be harmful or beneficial. [5, p. 53] It is the teacher; used methodology and teaching approach that are to do it beneficial.

Formative assessments help teachers to identify students' problems and needs; to assist students in developing a deep understanding of their own weak and strong points in learning. Knowing them can encourage students to take greater responsibility for their own learning progress.

The most common techniques that reflect the assessment operations are:asking questions during the learning process to find out what specific concepts or skills students have trouble with; - using «exit slips» or "exit tickets» or «admit slips» that help to get answers to a teacher's questions at the end or at the beginning of the lesson; - self-assessments and peer assessments that make students think about their own academic progress and realize what they still need to learn to meet their goals in learning.

Having received the responses the teacher make adjustments to the next lesson to discuss the points in which students have not had progress or skills they need to be developed. Formative assessments encourage students to reinforce their strong points rather than center on their fails.

When students are aware of their learning needs, they are more interested in their own educational progress and are they more responsible for it

\section{References:}

1. Alderson, J. C., Clapham, C., \& Wall, D. (1995). Language Test Construction and Evaluation. Cambridge: Cambridge University Press. 324 p.

2. Assessment Reform Group, Assessment for learning: Beyond the Black Box (1999), University of Cambridge School of Education, 12p., p. 4-5.

URL:https://www.researchgate.net/publication/271848977_Assessment_ for_Learning_beyond_the_black_box

3. Black, P.J. and Wiliam, D. (1998) 'Assessment and Classroom Learning', Assessment in Education, 5(1), 7-74.

4. Brown, D. (2004). Language Assessment. White Plains: Pearson Education, 324 p. 
5. Hughes, A. (2003). Testing for Language Teachers. 2nd Ed. Cambridge: Cambridge University Press, $132 \mathrm{p}$.

6. The Glossary of Educational Reforms, Last Updated 04.29.14, URL: https://www.edglossary.org/formative-assessment/

DOI https://doi.org/10.30525/978-9934-26-180-0-19

\title{
ОСОБЛИВОСТІ ЕКФРАСИСНОГО КОМПЛЕКСУ В ХУДОЖНЬОМУ ТА В РЕКЛАМНОМУ ТЕКСТІ
}

\author{
Іванченко А. В. \\ кандидат філологічних наук, \\ дочент кафедри іноземних мов \\ Одеський державний екологічний університет \\ Шотова-Ніколенко Г. В. \\ кандидат філологічних наук, доцент, \\ дочент кафедри іноземних мов \\ Одеський державний екологічний університет \\ Попович I. I. \\ викладач кафедри іноземних мов \\ Одеський державний екологічний університет \\ м. Одеса, Україна
}

Опис предметів мистецтва в художньому тексті відрізняється від опису експонатів виставки у каталогах та буклетах. У буклетах дається якась усереднена думка, прийнята мистецтвознавцями, художньою громадськістю, тобто у них відчувається претензія на об'єктивність, відстороненість, хоча подолати суб'єктивізм авторів цілком неможливо. В художньому тексті, насамперед, присутня суб'єктивна думка конкретних спостерігачів, - оповідача, персонажів.

Відмінності стосуються й емоційно-аксіологічної сфери. У буклетному (рекламному) екфрасисі рідко зустрічаються негативні характеристики. Як правило, тут превалюють меліоративні оцінки, оскільки прагматична мета буклету полягає в залученні якомога більшої кількості глядачів, тобто він виконує, насамперед, рекламну функцію. Реклама, як відомо, 